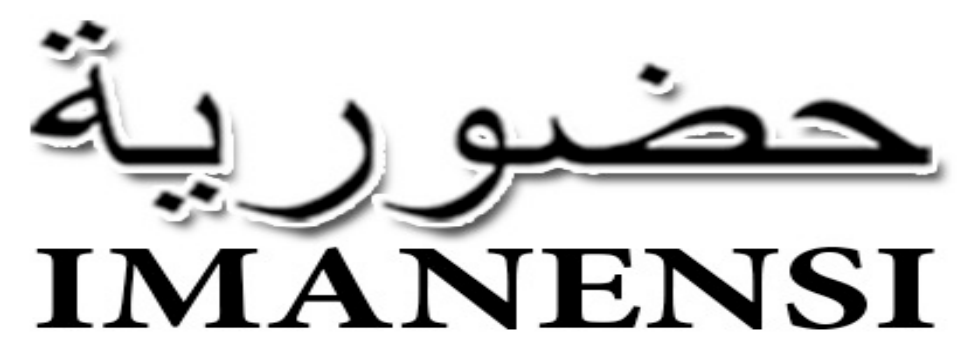

(Jurnal Ekonomi, Manajemen, dan Akuntansi Islam)

Vol 3, No 1, Maret 2108, H1mn. 37-48

\title{
Bumi dan corporate social responsibility
}

\author{
Nur Alim Bahri \\ a UIN Alauddin Makassar, Indonesia 92113 \\ 1*alimbahrinur.713@gmail.com
}

doi: 10.34202/imanensi.3.1.2018.37-48

\begin{abstract}
Abstrak
Artikel ini bertujuan untuk memahami bagaimana seharusnya peran CSR dalam penanggulangan kerusakan bumi Indonesia. Paradigma yang digunakan adalah paradigma kritis. Hasil Penelitian menunjukkan masih adanya kesalahan persepsi dalam penanggulangan kerusakan bumi Indonesia, pihak yang terkait masih hanya memikirkan materi. Tidak hanya itu adanya kolaborasi dari berbagai pihak juga sangat menentukan keberhasilan dalam menjaga dan melindungi keadaan bumi yang ada. Kerjasama yang baik akan menghasilkan hal yang baik pula, tidak hanya menjadi perenungan semata. Poin penting juga adalah regulasi, hal tersebut diharapkan bisa lebih mengikat oknum-oknum tidak bertanggungjawab.
\end{abstract}

Kata Kunci: Tanggung Jawab; Akuntansi lingkungan; Kerja Sama; Regulasi.

\section{Abstract}

This article aims to understand how the role of CSR should be in overcoming damage to Indonesia's earth. The paradigm used is the critical paradigm. The results of the study show that there are still misperceptions in overcoming damage to the Indonesian earth, the parties involved are still only thinking about the material. Not only that collaboration from various parties also determines success in maintaining and protecting the existing state of the earth. Good cooperation will produce good things too, not just mere reflection. An important point is also regulation, it is hoped that it can be more binding on irresponsible individuals.

Keywords: Responsible; Environmental Accounting; Cooperation; Regulation.

This is an open access article under the CC-BY-SA license.

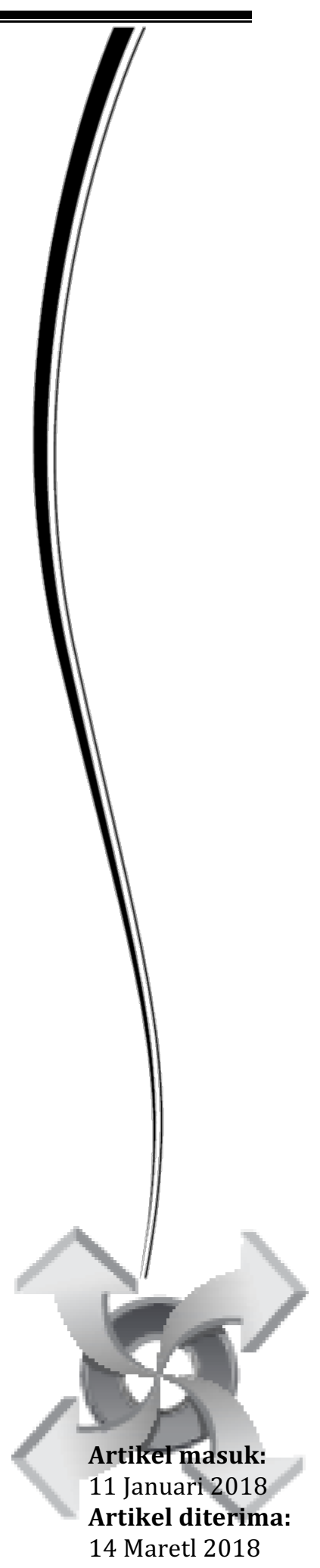




\section{Karena Tuhan akan senantiasa bersama dengan hambanya yang} terus "berjuang di jalan-Nya..."

Bumi menurut KBBI (Kamus Besar Bahasa Indonesia):

Planet tempat manusia hidup; dunia; jagat.

\section{Bumi menurut Oxford Dictionary:}

(n) The planet on which we live; the world.

Dari kedua pengertian di atas jelaslah bumi secara terminolgi dan pandangan tata bahasa manusia adalah sesuatu yang menjadi tempat tumpuan umat manusia untuk melangsungkan kehidupannya. Tempat manusia mencari makan, berkembang biak dan sebagainya. Dalam Oxford Dictionary dinyatakan bahwa bumi adalah sebagai benda yang dinyatakan oleh kelas katanya (n) yang berarti noun atau dalam bahasa Indonesianya ialah benda, lalu jika berbicara tentang benda maka pastilah memiliki umur atau masa pemakaian. Selain masa pakai, benda juga memiliki sifat dapat rusak atau berubah bentuk dan pada kebanyakan benda jika sudah rusak maka akan sulit untuk kembali ke bentuk awal diciptakannya. Jadi untuk menghambat kerusakan yang fatal bagi "si benda" maka manusia sebagai pemakainya harus merawatnya dengan penuh kasih sayang. Tapi bumi yang hakikatnya sebagai benda yang dapat rusak jika digunakan terus tanpa dirawat telah banyak dilupakan oleh manusia hari ini, manusia hari ini hanya berpikir untuk mengeksploitasi bumi untuk memuaskan nafsu kebendaannya semata. Terkadang mereka lupa mengenai benda apa yang paling penting untuk hidupnya. Jika eksploitasi besar besaran terus terjadi, ekosistem alam mulai rusak, tumbuhan tak dapat tumbuh lagi, hewan hewan pun tak dapat hidup lama, sumber makanan pun tak ada lagi, kekeringan dimana mana dan bumi menjadi tempat yang tak layak huni lagi bagi umat manusia, barulah mungkin mereka dapat tersadarkan bahwa materi yang selama ini mereka cari tidak untuk dapat dimakan.

Keadaan bumi hari ini telah berada pada masa yang memprihatinkan. Data dari lembaga PBB yang dikutip dari laman resminya yaitu un.org (2017) menyatakan bahwa pada abad 21 ini suhu permukaan bumi telah meningkat dan diprediksi melebihi 3 derajat celcius. Hal tersebut jika dibiarkan secara terus menerus akan berdampak pada perubahan iklim yang tidak dapat dikendalikan lagi. Jika perubahan iklim sudah tak dapat dikendalikan dan diprediksi lagi akan berdampak pada sumber pangan umat manusia, yaitu hewan dan tumbuhan. Tumbuhan yang tak dapat tumbuh semestinya dikarenakan adanya kenaikan suhu yang tidak biasa dan hewan yang membutuhkan tumbuhan sebagai makanannya juga tak dapat berkembang dengan baik dikarenakan keadaan tumbuhan yang tidak telah tercemar. Akhirnya kedua permasalahan tersebut akan berdampak pada perkembangan manusia sebagai puncak rantai makan di bumi ini.

Perubahan iklim merupakan tantangan global yang mempengaruhi semua penduduk di seluruh dunia. Perubahan iklim mengakibatkan perubahan pola cuaca, naiknya permukaan air laut, dan kejadian cuaca ekstrem lainnya. Hal tersebut dapat mengganggu ekonomi nasional, mempengaruhi kehidupan umat manusia, bahkan menelan korban jiwa.

Dewasa ini isu lingkungan menjadi komoditas global yang berkaitan dengan eksploitasi ekonomi, masyarakat dunia mulai peduli terhadap lingkungan mereka dan melakukan berbagai cara untuk memperbaiki kerusakan alam. Proses perubahan lingkungan telah terjadi dan akan terus berlangsung, yang saat ini telah mengakibatkan perubahan lingkungan baik secara kualitatif dan kuantitatif. Setiowati (2010) memberikan lima perbedaan perubahan lingkungan masa lalu dan masa kini, yaitu: 1) Perubahan lingkungan masa lalu berjalan sangat lambat; 2) Kerusakan lingkungan akhir-akhir ini bersifat global, melewati batas negara; 3) Kerusakan lingkungan masa kini telah menjangkau batas-batas generasi dan merugikan generasi mendatang; 4) Banyak kerusakan lingkungan sekarang bersifat tidak dapat dipulihkan kembali; dan 5) Masalah lingkungan tidak lagi terbatas masalah ekologi yang ditangani secara ilmiah belaka. 
Setiowati (2010) menyatakan bahwa perhatian para stakeholders terhadap kinerja lingkungan perusahaan semakin meningkat, yang disebabkan oleh isu pemanasan global yang semakin populer. Haque dan Islam (2012) dalam penelitiannya menemukan bahwa sejak tahun 2009 isu yang menjadi perhatian stakeholders terkait tanggung jawab sosial dan lingkungan adalah isu perubahan iklim akibat pemanasan global oleh gas rumah kaca. Aktivitas ekonomi secara langsung maupun tidak telah menjadi faktor penyebab terjadinya pemanasan global, dengan perusahaan sebagai penyumbang terbesar gas rumah kaca dikarenakan oleh berbagai proses produksi perusahaan (Shodiq dan Febri, 2015). Sehingga saat ini stakeholders menuntut masalah kerusakan lingkungan yang diakibatkan perusahaan harus menjadi tanggung jawab perusahaan, bukan tanggung jawab masyarakat (Setiowati, 2010).

Emisi gas rumah kaca dan penggunaan berbagai material yang mengandung Bahan Perusak Ozon (BPO) dari kegiatan manusia merupakan faktor pendorong terjadinya perubahan iklim. Emisi gas rumah kaca adalah pelepasan karbon ke atmosfer, terkait gas rumah kaca yang khususnya $\mathrm{CO} 2$ (gas terbesar yang dihasilkan oleh aktivitas manusia), yang terkait dengan proses produksi maupun penyediaan barang dan jasa perusahaan (Linggarsari, 2015). Pada 2014, menurut Purbaet al., (2017) total emisi gas rumah kaca Indonesia mencapai 1.808 juta ton CO2. Angka ini, secara konsisten mengindikasikan adanya kenaikan emisi dari tahun 2000-2013 sebesar 3,5 persen per tahun. Diantara lima sektor tersebut, sektor AFOLU (kehutanan, sektor pertanian dan lahan gambut) menjadi penyumbang emisi terbesar dengan kontribusi 60,44 persen, disusul sektor energi kedua dengan kontribusi sebesar 31,93 persen. Sektor kehutanan dan lahan gambut, terutama kebakaran hutan, adalah penghasil CO2 tertinggi sementara emisi sektor energi bergantung pada penggunaan konsumsi energi, terutama energi fosil. Dan jika telisik secara mendalam penyumbang emisi karbon terbesar menurut Shodiq dan Kartikasari (2009) adalah aktivitas operasional dari perusahaan, yang dimana perusahaan saat ini masih banyak yang menggunakan bahan bakar fosil sebagai sumber energinya.

Indonesia memiliki peranan penting di dunia, karena merupakan salah satu negara dengan hutan terluas di dunia. Hutan hujan tropis Indonesia menempati peringkat ketiga (sesudah Brazil dan Zaire) dalam kekayaan keanekaragaman hayati, sekaligus merupakan hutan hujan terluas di Asia. Hutan Indonesia diandalkan sebagai paru-paru dunia, serta diharapkan mampu menyumbang pada pengurangan emisi gas rumah kaca.

Luas hutan Indonesia mencapai 95 juta hektar atau sekitar 50,6 persen luas wilayah Indonesia (Purbaet al., 2017). Masing-masing kawasan memiliki fungsi dalam mendukung ekosistem dan ekonomi. Fungsi ekonomi hutan sebagai bahan baku industri, perdagangan luar negeri, dan konsumsi penduduk untuk makanan, bahan, dan energi telah memberi tekanan besar pada hutan. Total deforestasi di Indonesia pada 2014-2015 mencapai 1,09 juta hektar (KLHK, 2017). Deforestasi menurut KLHK (2015) merupakan perubahan kondisi penutupan lahan dari hutan menjadi bukan hutan (termasuk perubahan untuk perkebunan, permukiman, kawasan industri, dan lain-lain). Deforestasi menurut KLHK (2017) terluas terjadi di Pulau Sumatera, yaitu 519,0 ribu hektar atau 47,5 persen dari total deforestasi, kemudian pulau Kalimantan sebesar 34,3 persen. Salah satu penyebab tingginya deforestasi di 2015 karena kebakaran hutan seluas 250,9 ribu hektar. Hampir 75 persen area deforestasi dibiarkan menjadi lahan terbuka, lalu 9,5 persen menjadi semak belukar. Area deforestasi berasal dari hutan tanaman seluas 441,9 ribu hektar $(36,1$ persen) dan hutan rawa sekunder seluas 267,9 ribu hektar (21,9 persen).

Menurut laporan Greenpeace (2018) sektor perkebunan kelapa sawit dan bubur kertas merupakan pemicu tunggal terbesar penggundulan hutan di Indonesia dan Malaysia. Menurut angka-angka yang dikeluarkan oleh Kementerian Lingkungan Hidup dan Kehutanan (KLHK, 2017) Republik Indonesia, sekitar 24 juta hektar (ha) hutan hujan negara ini dihancurkan antara tahun 1990 dan 2015, sebuah wilayah yang hampir seluas negara Inggris, dengan kehilangan 1,6 juta ha lebih antara tahun 2015 dan 2017. Sekitar seperlima (19\%) dari deforestasi Indonesia antara tahun 2015-2017 terjadi di konsesi kelapa sawit. 
Dari data di atas jelas bahwasanya secara langsung perusahaan besar berskala internasional yang memiliki usaha di negeri telah berjasa besar dalam meningkatkan emisi gas rumah kaca di Indonesia. Hal tersebutlah yang mengakibatkan keadaan iklim dunia hari ini terkhususnya di Indonesia menjadi sudah tidak dapat diprediksi lagi, bencana banjir terjadi hampir di setiap daerah, kekeringan pun semakin menjadi jadi dan kematian satwa pun tak dapat terhindarkan dari kegiatan deforestasi ini.

Hal di atas menerangkan sekaligus memberikan dugaan bahwasanya regulasi pemerintah hari ini mengenai perlindungan alam dan perseroan terbatas sebagai pengelola sumber daya alam di Indonesia baik bagi perusahaan asing maupun Badan Usaha Milik Negara masih patut untuk diperbincangkan bersama mengenai kelangsungan alam Indonesia yang berada pada titik kritisnya. Hal tersebut dikarenakan kian hari perusakan alam di negeri ini tidak menemui perbaikan sama sekali, bahkan dirasa semakin bertambah parah.

\section{METODE}

Paradigma kritis pada dasarnya adalah paradigma ilmu pengetahuan yang meletakkan epistemologi kritik Marxisme dalam seluruh metodologi penelitiannya (Irwanto, 2013). Fakta menyatakan bahwa paradigma kritis yang diinspirasikan dari teori kritis tidak bisa melepaskan diri dari warisan Marxisme dalam seluruh filosofi pengetahuannya. Pengaruh ide Marxisme-Neo Marxisme dan teori kritis mempengaruhi filsafat pengetahuan dari paradigma kritis. Paradigma ini berasumsi realitas suatu hal yang tidak netral namun terikat oleh nilai serta kekuatan ekonomi, politik dan sosial. Sebab itu, paradigma kritis mengedepankan pembebasan nilai dominasi dari kelompok yang ditindas. Paradigma ini lebih dipahami sebagai proses katalisasi untuk membebaskan manusia dari segenap ketidakadilan (Rozi, 2014). Prinsipnya sudah tidak lagi bebas nilai, dan melihat realitas sosial menurut perspektif kesejarahan (historisitas). Paradigma ini menempatkan rakyat atau manusia sebagai subyek utama yang perlu dicermati dan diperjuangkan.

Menurut Tilling dan Carol (2013) tindakan kritis merupakan sebuah perpecahan yang telah melahirkan suatu konsep yang bertujuan untuk melestarikan budaya manusia dan nilai-nilai transedental tertentu, untuk menghidupkan kembali moralitas manusia dan digunakan dalam mengembangkan, mengeksplorasi dan mendukung berbagai perspektif dalam literature akuntansi. Asumsi dasar dalam paradigma kritis berkaitan dengan keyakinan bahwa ada kekuatan laten dalam masyarakat yang begitu berkuasa mengontrol proses komunikasi masyarakat. Ini berarti paradigma kritis melihat adanya "realitas" di balik kontrol komunikasi masyarakat

Paradigma kritikal melihat bahwa pengkonstruksian suatu realitas itu dipengaruhi oleh faktor kesejarahan dan kekuatan-kekuatan sosial, budaya, ekonomi, politik, dan media yang bersangkutan. Hal-hal kritis hadir untuk memecahkan suatu masalah atau situasi yang menimbulkan tanda tanya dan memerlukan upaya untuk mencari jawabannya serta penetapan fokus atau masalah dalam suatu riset yang bersifat kualitatif yang akan dipastikan sewaktu peneliti berada pada fenomena akuntansi yang diriset (Sukoharsono, 2014).

Paradigma kritis berangkat dari cara melihat realitas dengan mengasumsikan bahwa selalu saja ada struktur sosial yang tidak adil. Paradigma kritis (critical paradigm) mempunyai maksud dan implikasi praktis dan berpengaruh terhadap perubahan sosial. Paradigma ini tidak sekedar melakukan kritik terhadap ketidakadilan sistem yang dominan yaitu sistem sosial kapitalisme, melainkan suatu paradigma untuk mengubah sistem dan struktur tersebut menjadi lebih adil (Yasir, 2012).

Dalam penelitian paradigma kritis tujuannya ialah melihat bahwa objek atau realitas sosial yang diamati merupakan penampakan realitas semu (virtual reality) atau sekedar ekspresi kesadaran palsu (false consciousness) yang dimiliki manusia, bukan merupakan suatu realitas objektif, atau realitas yang sesuai dengan esensi sebenarnya yang diyakini seharusnya dimiliki manusia dan dunianya (Hidayat, 2002). Tujuannya antara lain untuk memperoleh temuan yang memiliki signifikansi sosial. 


\section{HASIL DAN PEMBAHASAN}

Pemanfaatan Alam dan Deforestasi dalam Kaca Mata Ekonomi. Pada tingkat nasional, hutan berperan penting sebagai modal pembangunan nasional dan memiliki manfaat yang nyata bagi kehidupan dan penghidupan bangsa Indonesia, baik manfaat ekologi, sosial budaya maupun ekonomi secara seimbang dan dinamis. Hutan mendukung siklus hidrologi yang menentukan daya dukung dan daya tampung daerah aliran sungai, karena secara tidak langsung menahan bencana banjir dan tanah longsor. Sebagai ekosistem yang kaya akan keanekaragaman hayati berupa beragam jenis hewan dan tumbuhan, hutan berperan dalam penyediaan jasa lingkungan dan tempat bergantung masyarakat yang hidup di sekitarnya.

Peran hutan bagi Indonesia semakin penting karena separuh wilayah Indonesia ditutupi hutan. Menurut data luas tutupan lahan Kementerian Lingkungan Hidup dan Kehutanan (KLHK, 2015) lahan berhutan di Indonesia seluas 95 juta hektar, atau sekitar 50,6 persen dari wilayah Indonesia.

Masing-masing kawasan hutan mempunyai fungsi dalam mendukung ekosistem maupun ekonomi. Produksi hasil hutan penting bagi pemenuhan konsumsi masyarakat, industri dan pemenuhan ekspor. Dalam mendukung fungsi ekonomi hutan, eksploitasi dapat dilakukan sesuai daya dukung hutan dengan mempertimbangkan kelestarian kawasan hutan. Pemerintah khususnya KLHK mengeluarkan berbagai izin yang terkait fungsi hutan dalam mendukung perekonomian, di antaranya izin usaha pemanfaatan kayu, izin industri primer hasil hutan, izin pinjam pakai kawasan hutan untuk usaha pertambangan, sampai izin pelepasan kawasan hutan untuk perkebunan dan pertanian tanaman pangan.

Fungsi hutan dalam mendukung perekonomian khususnya industri dalam negeri diharapkan mampu menghasilkan nilai tambah dan menciptakan lapangan pekerjaan. Berikut ini beberapa aktivitas produksi ekonomi yang terkait dengan kawasan hutan (Prabu et al.,2017), yaitu: 1) Industri perkayuan. Dalam industri perkayuan hutan berperan sebagai penyedia utama. Dalam satu dasawarsa terakhir, industri bubur kertas dan industri produk perkayuan semakin meningkat. Bukan hanya untuk memenuhi kebutuhan pasar domestik, namun juga memenuhi pasar luar negeri sehingga meningkatkan pendapatan negara dan memberikan kontribusi positif terhadap perekonomian bangsa. Untuk total jenis produk kayu gergajian, kayu lapis, papan tipis, serpih kayu dan bubur kertas pada tahun 2016 menghasilkan 4,06 miliar US\$. Ekspor dari komoditi kayu lapis saja menghasilkan 2,24 miliar US\$, dan bubur kertas sebesar 1,62 milliar US\$; 2) Perkebunan. Salah satu sub sektor pertanian yang cukup besar potensinya adalah sub sektor perkebunan. Kontribusi sub sektor perkebunan dalam Produk Domestik Bruto (PDB) yaitu sekitar 3,57 persen pada tahun 2015 atau merupakan urutan pertama di Sektor Pertanian, Peternakan, Perburuan dan Jasa Pertanian. Produksi perkebunan terbesar di Indonesia adalah kelapa sawit, dan Indonesia merupakan eksportir kelapa sawit terbesar dunia. Produksi kelapa sawit tahun 2015 mencapai 31,28 juta ton atau meningkat 35,45 persen dari tahun 2011 atau rata-rata meningkat 7,92 persen setiap tahunnya.

Selanjutnya 3) Pertambangan dan energi. Permintaan dan konsumsi bahan tambang terutama sebagai sumber energi sangat terkait dengan aktivitas ekonomi, karena penggerak perekonomian terutama aktivitas produksi adalah energi. Sektor pertambangan dan penggalian memberikan peran 10,5 persen dari total PDB Indonesia tahun 2014, tetapi angka ini menunjukkan tren yang cenderung menurun; 4) Pertanian dan tanaman pangan. Peran hutan yang dirasa cukup besar pengaruhnya sampai ke akar rumput adalah sebagai penyedia lahan untuk pertanian terutama pertanian tanaman pangan. Kebutuhan ini semakin meningkat seiring meningkatnya jumlah penduduk. Di Indonesia, tanaman pangan dengan jumlah produksi terbesar tahun 2016 adalah padi sebagai makanan pokok mayoritas penduduk Indonesia yaitu 79,2 juta ton, dan jagung sebesar 23,2 juta ton. 
Keadaan Alam Indonesia Hari Ini. Dari penjelasan di atas tentulah pengeksploitasian alam sebagai sumber mata pencaharian menjadi sangat menggiurkan. Terlebih lagi lingkungan alam Indonesia yang terkenal akan kekayaan dan keanekaragaman biotanya. Hal tersebut juga dibarengi dengan kesuburan tanah Indonesia yang begitu mengagumkan. Di tanah ini boleh dikata apapun dapat tumbuh walaupun tanpa adanya bantuan formula formula kimiawi seperti pupuk dan sebagainya. Maka dari hal tersebutlah tanah Indonesia menjadi komoditi favorit perusahaan multinasional untuk dijadikan ladang usaha mereka.

Tapi sayangnya semakin banyak pembukaan usaha di tanah Indonesia ini tidak dibarengi dengan regulasi yang memadai untuk setidaknya menjaga kelangsungan hidup keanekaragaman hayati di negeri ini. Banyaknya pemberitaan dimana mana yang menghiasi media cetak dan komunikasi terkait pengrusakan alam telah banyak menjadi pemberitaan yang dapat dinikmati setiap harinya di negeri ini. Lumpur Sidoarjo, pembakaran perkebunan kelapa sawit di Sumatera dan Kalimantan serta penggundulan hutan menjadi hal yang lumrah bagi telinga masyarakat Indonesia hari ini. Hal tersebut mengisyaratkan tentang kurangnya pemerintah dalam menyikapi hal tersebut.

Menurut laporan Greenpeace (2018) sektor perkebunan kelapa sawit dan bubur kertas merupakan pemicu tunggal terbesar penggundulan hutan di Indonesia dan Malaysia. Menurut angka-angka yang dikeluarkan oleh Kementerian Lingkungan Hidup dan Kehutanan (KLHK, 2017) Republik Indonesia, sekitar 24 juta hektar (ha) hutan hujan negara ini dihancurkan antara tahun 1990 dan 2015, sebuah wilayah yang hampir seluas negara Inggris, dengan kehilangan 1,6 juta ha lebih antara tahun 2015 dan 2017. Sekitar seperlima (19\%) dari deforestasi Indonesia antara tahun 2015-2017 terjadi di konsesi kelapa sawit.

Pengrusakan hutan hujan Indonesia adalah salah satu krisis global. Deforestasi dan pengrusakan lahan gambut adalah sumber utama emisi gas rumah kaca; pengrusakan hutan hujan telah menempatkan Indonesia menjadi salah satu penghasil emisi global terbesar, di samping Amerika Serikat dan Cina.

Pengembangan perkebunan merupakan akar penyebab kebakaran hutan dan lahan gambut di Indonesia, di mana banyak kebakaran merupakan kegiatan disengaja untuk membersihkan lahan sebelum penanaman. Pada bulan Juli 2015, kebakaran hutan dan lahan gambut yang menghancurkan, meluas di banyak wilayah Sumatra, Kalimantan dan Papua menghentikan operasi penerbangan serta memaksa penutupan sekolah dan kantor di seluruh wilayah tersebut. Selama bulan September dan Oktober 2015, emisi gas rumah kaca (GRK) harian dari kebakaran hutan di Indonesia menyumbang sebanyak 1,62 miliar metrik ton karbon dioksida ke langit (Harris et al., 2015 dalam Greenpeace, 2018). Kebakaran-kebakaran ini juga menghasilkan kabut asap yang merugikan jutaan orang di Asia Tenggara, para peneliti di Universitas Harvard dan Columbia memperkirakan, bahwa 100.000 orang mengalami kematian dini akibat penyakit pernapasan yang terkait dengan kabut asap tahun 2015dan bank dunia menghitung biaya kerugian akibat bencana ini mencapai US\$ 16 miliar (Koplizt et al., 2016).

Deforestasi untuk perkebunan bubur kertas dan kelapa sawit telah menghancurkan hutan-hutan dataran rendah di Sumatra dan Kalimantan, menghancurkan habitat penting untuk harimau, gajah, badak, orang utan dan spesies terancam punah lainnya. Para ilmuwan memperkirakan bahwa hanya tersisa dua populasi kembang biak yang layak dari harimau Sumatra di alam liar (Luskin et al., 2017). Jumlah orang utan Borneo mengalami penurunan lebih dari 50\% antara tahun 1999 dan 2015, dengan tidak lebih dari 70.000-100.000 ekor yang tersisa (Voight et al., 2018). Pada tahun 2015-2017, lebih dari seperempat (28\%) dari hilangnya habitat orang utan Borneo di hutan Indonesia terjadi di konsesi kelapa sawit. Lebih dari $69 \%$ habitat potensial untuk gajah Sumatra telah dihancurkan hanya dalam satu generasi. Badak Sumatera dikatakan dalam kondisi kritis, dengan kurang dari 100 ekor yang tersisa di alam liar (Greenpeace, 2018). Krisis di Indonesia berisiko kembali terjadi karena industri kelapa sawit meluas ke negara-negara dan wilayah-wilayah baru: menurut Lembaga konservasi dunia, International Union for Conservation of Nature (IUCN), kawasan yang belum dikembangkan dan cocok untuk 
produksi minyak sawit merupakan tempat tinggal bagi setengah dari mamalia terancam di dunia, dan hampir dua pertiga dari semua burung yang terancam (Meijaard et al., 2018).

Peran Pemerintah dalam Melawan Perusahaan Perusak Alam. Dari data di atas cukuplah untuk dapat menggambarkan bagaimana kerusakan lingkungan alam Indonesia hari ini yang diakibatkan oleh banyaknya pembukaan lahan oleh perusahaan perusahaan perkebunan maupun pertambangan. Jika dikaji lebih mendalam pengrusakan alam yang digambarkan di atas barulah berasal dari dua jenis pengelolaan alam saja tetapi dampaknya sudah sangat teramat menyedihkan. Hal tersebut secara tidak langsung menampar wajah pemerintah masa ini akan bagaimana kinerjanya dalam melindungi alam Indonesia hari ini.

Jika mengukur kinerja suatu pemerintahan dari seberapa banyak regulasi yang telah mereka susun sebenarnya untuk menghakimi pemerintahan hari ini terkait kerusakan alam yang terjadi maka dapat dikatakan pemerintah periode ini tidak sepenuhnya gagal dalam menjalankan kinerjanya terkait perlindungan terhadap kerusakan alam. Hal tersebut dikarenakan menurut Prabu et al., (2017) bahwa sejauh ini pemerintah telah menyusun regulasi atau landasan hukum untuk melindungi lingkungan alam Indonesia, regulasi tersebut berupa undang-undang, peraturan pemerintah, keputusan presiden, maupun peraturan menteri. Sejauh ini terdapat 3 peraturan di bidang perlindungan dan pengelolaan lingkungan hidup, 2 peraturan di bidang pengelolaan sampah, 16 peraturan di bidang perlindungan dan pengelolaan air, 7 peraturan di bidang pengelolaan bahan berbahaya dan beracun (B3), 16 peraturan di bidang pengelolaan limbah bahan berbahaya dan beracun (LB3), 6 peraturan di bidang perlindungan dan pengelolaan keanekaragaman hayati, 3 peraturan di bidang perlindungan dan pengelolaan tutupan lahan, 3 peraturan di bidang pelestarian fungsi atmosfer, 9 peraturan mengenai Instrumen Perlindungan dan Pengelolaan Lingkungan Hidup, 2 peraturan kapasitas sumber daya manusia, dan 6 perjanjian internasional. Peraturan tentang pengelolaan polutan dibagi dua, yaitu pengelolaan bahan berbahaya dan beracun (B3) berjumlah 7 peraturan, dan pengelolaan limbah bahan berbahaya dan beracun (LB3) berjumlah 16 peraturan.

Namun disisi lain jika ditelaah lebih mendalam mengenai berbagai regulasi di atas maka tidak dapat ditemukan satupun regulasi yang mengatur secara jelas mengenai standarisasi format yang harus digunakan dalam pelaksanaan regulasi terkait perlindungan alam dan pertanggung jawaban sosial perusahaan di lapangan. Hal tersebut juga dijelaskan oleh Muallidin dan Suryono (2015) bahwa Pengaturan pengelolaan program CSR menimbulkan berbagai persoalan praktis di lapangan. Misalnya, dari sisi format yang tidak sama, bentuk perundangan, serta isi ketentuan yang berbeda. Seperti tidak adanya kelembagaan daerah yang jelas yang menjadi pengawas pelaksanaan program tersebut, munculnya bermacam tafsir terhadap penggunaan dana CSR, ketidakjelasan hak dan kewajiban perusahaan pemerintah maupun masyarakat penerima program, dan sistem evaluasi pelaksanaan CSR yang rancu. Ketidakharmonisan muncul juga karena tidak adanya standar acuan yang diberikan oleh pemerintah pusat bagi pemerintah daerah dalam mengatur pengelolaan program CSR. Standard acuan tersebut tentunya harus dirumuskan dalam bentuk model kebijakan yang mengakomodasi kepentingan pemerintah daerah, perusahaan dan masyarakat, tanpa menyampingkan kaidah-kaidah hukum perundangan yang berlaku. Sehingga harmonisasi ini dapat mengurangi hambatan dan menjaga efektivitas bekerjanya peraturan perundang-undangan bagi pemerintah daerah.

Tetapi terlepas dari pertentangan di atas sebenarnya, hadirnya Negara sebagai penyelenggara Pemerintahan yang menggunakan organ-organ untuk menjalankan fungsinya, khususnya dalam pelaksanaan CSR yang telah menjadi kewajiban hukum ialah sebagai badan yang berkomitmen untuk menjaga keharmonisan masyarakat dan perseroan untuk tetap berinteraksi sosial seraya tunduk dalam pengaturan dan pengawasan aturan perundangan yang berlaku.

Sebenarnya yang menjadi titik fokus yang menjadi harapan pemerintah bagi perseroan yang menjalankan usahanya di Indonesia, baik itu yang sumber daya 
utamanya berasal dari alam Indonesia maupun yang tidak, harus berpedoman pada tiga pilar yaitu sosial, ekonomi dan lingkungan. Hal tersebut dijabarkan oleh Elvinaro et al., (2011) ialah, 1) Profit. Perusahaan harus tetap berorientasi untuk mencari keuntungan ekonomi yang memungkinkan untuk terus beroperasi dan berkembang; 2) People. Perusahaan harus tetap memiliki kepedulian terhadap kesejahteraan manusia. Beberapa perusahaan telah mengembangkan program tanggung jawab sosial, seperti pemberian beasiswa bagi pelajar di sekitar perusahaan, pendirian sarana pendidikan dan kesehatan, penguatan kapasitas ekonomi lokal dan lain-lain. 3) Planet. Perusahaan harus peduli terhadap lingkungan hidup dan berkelanjutan keragaman hayati. Bebarapa program tanggung jawab sosial yang berpijak pada prinsip ini biasanya penghijauan lingkungan hidup, penyediaan sarana air sehat, perbaikan pemukiman, pengembangan pariwisata.

Peran IAI dalam Perlindungan Lingkungan Alam Indonesia. Dewasa ini selain dihadapkan dengan permasalahan peningkatan profitabilitas, perusahaan juga dituntut untuk peka terhadap permasalahan lingkungan akibat dari pengoperasian usahanya. Selain dari itu sebuah perusahaan juga harus mampu mengontrol potensi finansial maupun potensi non finansial di dalam meningkatkan nilai perusahaan untuk eksistensi perusahaan dalam jangka panjang (Munawaroh, 2014). Hal tersebut mengindikasikan bahwa nama baik suatu perusahaan dimata shareholder tidak boleh luput dari tujuan perusahaan demi menjaga keberlanjutan usahanya. Sedangkan disisi lain pengendalian atas eksploitasi alam yang dilakukan oleh perusahaan dalam pengoperasian usahanya dirasa sangat perlu untuk dimintai pertanggungjawaban akan hal tersebut. Kebutuhan akan keharusan agar diadakannya suatu pertanggung jawaban sosial atas dampak pengeksploitasian alam bertujuan untuk mengetahui sejauh mana peran perusahaan pada lingkungannya, baik itu yang berdampak baik dan buruk.

Secara umum konsep pertanggung jawaban sosial perusahaan masa kini atau yang biasa dikenal sebagai CSR sebenarnya bertumpu pada suatu kesamaan pemahaman yaitu tentang bagaimana perusahaan menjalin relasi yang baik dengan lingkungannya sebagai pembantu pemerintah dengan ikut andil dalam menyejahterakan masyarakat, menjaga kelestarian alam dan secara tidak langsung menaikkan nilai perusahaannya sendiri di mata masyarakat (Kotler dan Lee, 2005; Wibisono, 2007; Lindawati dan Puspita, 2015). Lalu jika menelisik pada UU No. 40 tahun 2007 dan UU No. 25 tahun 2007 pemahaman mengenai CSR yang telah dijelaskan sebelumnya tidaklah terlalu jauh dari maksud peraturan ini.

Corporate Social Responsibility jika diperhadapkan dengan ilmu akuntansi tentulah memiliki suatu keterikatan yang begitu erat. Hal tersebut dikarenakan baik secara langsung maupun tidak langsung CSR dapat mempengaruhi arus keuangan perusahaan. Hal tersebut tercermin dalam setiap laporan keuangan suatu entitas bisnis mengenai jumlah biaya CSR yang dikeluarkan setiap tahunnya.

Namun hal tersebut belum dibarengi dengan adanya suatu standar pelaporan keuangan yang dapat menaungi pertanggung jawaban sosial perusahaan secara komprehensif. Hal ini mungkin belum memiliki daya tarik bagi IAI sebagai kompartemen yang menaungi dunia akuntansi Indonesia untuk segera menyusun suatu regulasi terkait hal ini. Menurut Fatwatie (2015) PSAK yang disusun oleh IAI belum sama sekali mengatur secara tegas mengenai sesuatu yang mengharuskan perusahaan untuk melaporkan tanggung jawab sosial mereka. Pengelompokan, pengukuran dan pelaporan juga belum diatur, jadi untuk pelaporan tanggung jawab sosial diserahkan pada masing-masing perusahaan. Akibatnya terdapat multitafsir dalam menyikapi PSAK No. 1, sehingga kemungkinan akan berdampak pada tidak seriusnya perusahaan dalam mengungkapkan tanggung jawab sosialnya yang berakibat pula pada berbedanya tingkat pengungkapan sosial antar perusahaan.

Terlepas dari ada atau tidaknya mengenai regulasi akuntansi tentang pertanggung jawaban sosial ini akuntansi tidak bisa lepas dari berbagai pengeksploitasian lingkungan alam oleh perusahaan. Maka boleh dikata secara tidak langsung IAI memiliki peran atas kerusakan alam di negeri ini. Hal tersebut dikarenakan IAI sebenarnya memiliki kekuatan yang dapat mempengaruhi seluruh 
kegiatan perusahaan untuk mengikuti kehendaknya karena telah beroperasi di Indonesia. Kekuatan tersebut berupa kuasa dalam menentukan penyajian akun akun yang harus ada pada laporan keuangan suatu perusahaan. Terlebih lagi kuasa tersebut diperbolehkan selama tidak bertentangan dengan IFRS. Apalagi permasalahan ini berdampak pada lingkungan alam yang notabene telah menjadi fokus utama bangsa bangsa di dunia selain dari kelaparan dan kesejahteraan.

Peran Sosial Perusahaan terhadap Pengelolaan Alam. Pada masa sekarang perusahaan diperhadapkan pada bagaimana mereka memenuhi kepentingan benyak pihak.Pihak-pihak ini disebut juga sebagai para pemangku kepentingan (stakeholders), yaitu pihak yang memengaruhi atau akan dipengaruhi oleh keputusan dan strategi perusahaan (Clarkson, 2011).Hal tersebut digambarkan Triyuwono (2015) mengenai konsep perusahaan dan pengoperasiannya yang didasarkan atas tujuan untuk memaksimalkan keuntungan untuk memenuhi kepentingan para homo economicus (stakeholders). Menurut Thaler (2000); Sigmund (2010); Xin dan Li (2013) inti dari homo economicus ialah untuk memaksimalkan kepentingan diri untuk semakin meningkatkan kekayaannya. Selain dari homo economicus, menurut Jensen \& Meckeling (1994) dalam karakteristik alamiah manusia terdapat pula karakteristik homo sociologicus yang dimana homo sociologicus ini tidak terlalu memiliki kepentingan akan pendapatan yang akan ia terima, tetapi hanya memiliki perhatian pada lingkungan sosialnya, sifat psikologi apa yang dibutuhkan oleh manusia dan nama baiknya di mata orang lain.

Maka berangkat dari hal tersebutlah perusahaan sekarang ini tidaklah dapat lepas dari bagaimana keadaan alam sekitarnya. Perusahaan mau tidak mau pasti memiliki dampak terhadap perubahan lingkungan alam sekitarnya, baik itu oleh perusahaan yang sumber daya utamanya langsung bersumber dari alam maupun yang tidak. Meskipun sumber daya utama suatu perusahaan tidak langsung berhubungan dengan alam tetapi pasti setiap perusahaan memiliki limbah dari hasil pengoperasiannya, maka dari hal tersebutlah yang langsung bersinggungan dengan alam. Sedangkan jika hal tersebut tidak ditanggulangi secara komprehensif maka kerusakan alam tidaklah dapat terhindarkan lagi, misalnya saja lumpur Lapindo di Sidoarjo yang hingga hari ini tidak kunjung menunjukkan tanda-tanda untuk dapat dikembalikan pada bentuk asalnya.

Maka dari hal tersebutlah dibutuhkannya peran perusahaan dalam perlindungan alam di setiap negara dunia. Sebenarnya ada tiga tujuan akuntansi pertanggung jawaban sosial yaitu (Usmansyah, 1989): 1)Untuk mengidentifikasikan dan mengukur sumbangan sosial netto periodik dari suatu perusahaan, yang meliputi bukan hanya biaya dan manfaat yang diinternalisasikan ke dalam perusahaan, namun juga yang timbul dari eksternalitas yang mempengaruhi bagianbagian sosial yang berbeda; 2) Untuk membantu menentukan apakah praktik dan strategi perusahaan yang secara langsung mempengaruhi sumber daya relatif dan keadaan sosial adalah konsisten dengan prioritas-prioritas sosial pada satu sisi dan aspirasi-aspirasi individu pada sisi lainnya; 3) Untuk menyediakan dengan cara yang optimal bagi semua kelompok sosial, informasi yang relevan mengenai tujuan, kebijakan, program, kinerja dan sumbangan perusahaan pada tujuan-tujuan sosial.

Sebenarnya Corporate Social Responsibility tidak hanya menambah biaya namun dapat berguna sebagai alat marketing bagi perusahaan apabila CSR dilaksanakan berkesinambungan (Amanda, 2016).Maka dari hal tersebut sebenarnya biaya CSR ini bisa dikatakan selain dari aspek pengeluaran yang wajib dilakukan oleh perusahaan CSR ini pun menjadi alat investasi yang menjanjikan bagi keberlangsungan perusahaan kedepannya. Investasi ini merupakan sesuatu yang tak dapat diukur oleh nilai uang tetapi dapat menghasilkan kenaikan nilai pendapatan perusahaan secara tidak langsung. Substansi CSR sendiri bukan pada aspek penghimpunan dana dan pembangunan infrastruktur semata, tapi bagaimana perusahaan mampu mengintegrasikan perhatian terhadap aspek sosial dan lingkungan dalam operasi bisnis mereka dan dalam interaksinya dengan para pemangku kepentingan (stakeholders) berdasarkan prinsip kesukarelaan pada awalnya (Suprapto, 2012). Dan disisi lain secara tidak langsung peningkatan reputasi 
perusahaan dapat terwujud apabila perusahaan dapat menyesuaikan diri dengan kepentingan para stakeholdernya (Dickinson etal.,2010). Adapun beberapa metode pengukuran akuntansi sosial, menurut Harahap (2002) yaitu: 1) Menggunakan Opportunity Cost Approach, misalnya atas pembuangan limbah suatu perusahaan, dapat dihitung social cost dengan cara menghitung kerusakan wilayah rekreasi sebagai akibat pembuangan limbah tersebut, kerugian manusia dalam hidupnya, berapa berkurang kekayaannya; 2) Menggunakan daftar kuesioner, survey, lelang, dimana mereka yang merasa dirugikan ditanyai berapa besar jumlah kerugian yang ditimbulkannya atau berapa biaya yang harus dibayar kepada mereka sebagai kompensasi kerugian yang dideritanya; 3) Menggunakan hubungan antara kerugian massal dengan permintaan untuk barang perorangan dalam menghitung jumlah kerugian masyarakat; 4) Menggunakan reaksi pasar dalam menentukan harga. Misalnya vonis hakim akibat pengaduan masyarakat akan kerusakan lingkungan dapat juga dianggap sebagai dasar perhitungan

\section{SIMPULAN}

Tanggung jawab sosial perusahaan adalah kepedulian perusahaan terhadap kepentingan pihak-pihak lain secara lebih luas daripada sekedar terhadap kepentingan perusahaan belaka. Maka dari berbagai penjabaran sebelumnya, kesimpulan yang dapat ditarik dari pengelolaan Corporate Social Responsibility hari ini yang terjadi di Indonesia masih ditemukan berbagai macam kekurangan yang terjadi. Secara tidak langsung kekurangan tersebut jika ditelaah secara kritis merupakan sesuatu yang sangat penting untuk segera diwujudkan dan tak dapat menunggu lagi karena kerusakan alam yang terjadi semakin menjadi jadi.

Kerja sama di antara berbagai pihak selayaknya dilakukan untuk menjaga dan melindungi keadaan alam yang ada. Selain dari kerja sama ini, suatu kesadaran akan pentingnya menjaga keharmonisan alam yang ada merupakan sesuatu yang patut direnungkan bersama. Regulasi yang ketat pun sangat dibutuhkan untuk melindungi alam dari oknum-oknum nakal yang hanya memikirkan ego memperkaya dirinya sendiri tanpa mempertimbangkan lingkungan sekitarnya.

Dari penjabaran di atas maka tidaklah mengherankan jika setiap perusahaan sekarang ini diwajibkan untuk melaksanakan pertanggung jawaban sosialnya. Karena setiap perusahaan pasti memiliki dampak terhadap lingkungan sekitarnya. Pengelolaan CSR diperlukan hati nurani setiap individu dalam perusahaan untuk melaksanakan tanggung jawab sosial ini. Tentu saja hal ini akan bermanfaat bagi kehidupan perusahaan dalam jangka panjang. Karena tentunya masyarakat akan mendukung setiap kegiatan yang dilakukan perusahaan asalkan tidak merugikan yang ada di sekitarnya dan secara tidak langsung akan menambahkan kepercayaan dan nama baik suatu perusahaan dimata masyarakat akan usaha dan produk yang dihasilkannya.

\section{DAFTAR PUSTAKA}

Amanda, Ramantha \& Wirakusuma.(2016). Dampak Moderasi Profitabilitas Terhadap Pengaruh Corporate Social Responsibility Pada Nilai Perusahaan Manufaktur.E-jurnal Fakultas Ekonomi dan Bisnis Universitas Udayana.

Clarkson, M. (1995). A Stakeholder Framework for Analyzing and Evaluating Corporate Social Performance. Academy of Management Review. 20(1), 92117.

Dickinson, S. D. M. Beverland \& A Lindgreen. (2010). Building Corporate Reputation with Stakeholders. EuropeanJournal of Marketing. 44 (11), 1856 - 1874.

Elvinaro \& Dindin M. (2011). Efek kedermawanan dan CSR.Jakarta: PT. Elex Media Komputindo.

Fatmawatie, Naning. (2015). Pengungkapan Corporate Social Responsibility (CSR) dalam Akuntansi Sosial Ekonomi Ditinjau dari Syariah. Jurnal Ekonomi Syariah. 3 (2), 221- 237.

Greenpeace.(2018). Hitung Mundur Terakhir. Belanda: Greanpeace International.

Harahap, Sofyan Syafri. (2002). Teori Akuntansi. Edisi Revisi.Jakarta: PT. Raja Grafindo Persada. 
Haque, Shamima \& Muhammad Azizul Islam. (2012). Stakeholder Pressures and Climate Change Disclosure: Australian Evidence. Open Confrence Proceeding AFAANZ Melbourne.

Jensen, M.C. \& Meckling W. H. (1994). The Nature of Man. Journal of Applied Corporate Finance. 7, 4-19.

KLHK (Kementerian Lingkungan Hidup dan Kehutanan. (2015). Deforestasi Indonesia Tahun 2013-2014. Jakarta.

KLHK (Kementerian Lingkungan Hidup dan Kehutanan). (2017). Deforestasi Indonesia Tahun 2014-2015. Jakarta.

Kotler, P dan N Lee.(2005).Corporate Social Responsibility: Doing the Most Good for Your Company and Your Cause.New Jersey: John Wiley and Sons.

Koplitz, Shannon N., Loretta J Mickley, Miriam E Marlier \& Jonathan J Buonocore. (2016). Public health impacts of the severe haze in Equatorial Asia in September-October 2015: demonstration of a new framework for informing fire management strategies to reduce downwind smoke exposure. Environment Research Letters. 11 (2016) 094023.

Lindawati, Ang Swat Lin \& Marsella Eka Puspita. (2015). Corporate Social Responsibility: Implikasi Stakeholder dan Legitimacy GAP dalam Peningkatan Kinerja Perusahaan. Jurnal Akuntansi Multiparadigma.6(1), 157-174.

Linggasari, Elsa. (2015). Pengaruh Karakteristik Perusahaan Terhadap Carbon Emission Disclosure (Studi pada Perusahaan Manufaktur yang Terdaftar di Bursa Efek Indonesia Periode 2011-2013). Diponegoro Journal of Accounting. $1-18$.

Luskin, M.S., Wido Rizki Albert \& Mathias W. Tobler. (2017). Sumatran Tiger Survival Threatened by Deforestation Despite Increasing Densities in Parks. Nature Communication. 8(1).

Meijaard, E., Garcia-Ulloa, J., Sheil, D., Wich, S.A., Carlson, K.M., Juffe-Bignoli, D., and Brooks, T.M. (2018). Oil palm and biodiversity. A situation analysis by the IUCN Oil Palm Task Force. Switzerland: IUCN Oil Palm Task Force.

Muallidin, Isnaini \&Leli Joko Suryono. (2015). Model Kebijakan Pemerintah Daerah dalam Pengelolaan Program Tanggung Jawab Sosial Perusahaan Berbasis Regulasi Daerah. Jurnal Media Hukum. 22 (1), 128-139.

Munawaroh, Aisyatul. (2014). Pengaruh Profitabilitas Terhadap Nilai Perusahaan Dengan Corporate Social ResponsibiltySebagai Variabel Moderating. Jurnal Ilmu \& Riset Akuntansi. 3 (4).

Setiowati, Ardhy Pratiwi.(2010). Analisis Hubungan Kinerja Lingkungan dan Kinerja Keuangan Perusahaan Pertambangan. Economic Review Journal Universitas Indonesia. 1-27.

Shodiq, M. Ja'far \& Lisa Kartikasari. (2009). Carbonaccounting: Implikasi Strategis Perekayasaan Akuntansi Manajemen. Simposium Nasional Akuntansi XII, Palembang.

Shodiq, M. Ja'far \& Yogi Trisita Febri. (2015). Sistem Akuntansi dan Pelaporan Emisi Karbon: Dasar Pengembangan Standar Akuntansi Karbon (Studi ekplorasi pada perusahaan manufaktur di BEI). Simposium Nasional Akuntansi XVII Medan.

Sigmund, K. (2010). The Calculus of Selfishness. Princeton: Princeton University Press.

Suprapto. (2012). Kewenangan Pengelolaan Tanggung Jawab Sosial Perusahaan (CSR) Pada Era Otonomi Daerah. Jurnal Ilmu Hukum. 7 (2).

Thaler, R. H. (2000). From Homo Economicus to Homo Sapiens. The Journal of Economic Perspectives. 14, 133-141.

Triyuwono, Iwan. (2015). Awakening The Conscience Inside: The Spirituality of Code of Ethics for Professional Accountants. Procedia-Social and Behavioral Sciences. $172,254-261$.

United Nations. (2017). Goal 13 : Take Urgent Action to Combat Climate Change and Its Impacts.http://www.un.org/ sustainable development/ climatechange-2/. Diakses pada tanggal 15 Des 2018.

Usmansyah. (1989). Telaah Alternatif Penerapan Akuntansi Pertanggungjawaban Sosial Di Indonesia. Akutansi. (10) 
Bahri, N. A.

Bumi dan ....

Purba, Winda Sartika, Pramudya Ajeng Safitri dan Riski Andianti. (2017). Statistik Lingkungan Hidup Indonesia 2017. Jakarta: Badan Pusat Statistik Indonesia/BPS.

Voight, Maria, Serge A. Wich, Marc Ancrenaz, et al.(2018). Global Demand for Natural Resources Eliminated More Than 100,000 Bornean Orangutans. Current Biology. 28(5): 761-769

Wibisono, Y. (2007). Membedah Konsep \& Aplikasi CSR. Gresik: Fascho Publishing. Xin, Z. \& Liu, G. (2013). Homo Economicus Belief Inhibits Trust. PLoS ONE. 8 (10). 